\title{
EVALUATION OF TRUNK AS THE MOST FLESHY REGION OF SOME FISH SPECIES FROM THE WARRI RIVER, DELTA STATE, NIGERIA
}

\author{
EDEMA C.U. and J.E. SIMIRE \\ Department of Animal and Environmental Biology \\ University of Benin, Benin City
}

Copyright 2010, Fisheries Society of Nigeria.

This paper was prepared for presentation at the $25^{\text {th }}$ Annual International Conference and Exhibition in Administrative Staff College of Nigeria (ASCON), Topo-Badagry, Lagos, Nigeria, $25^{\text {th }}-29^{\text {th }}$ October, 2010.

This paper was selected for presentation by an FISON Program Committee following review of information contained in an abstract submitted by the author(s). Contents of the paper, as presented, have not been reviewed by the Fisheries Society of Nigeria and are subject to correction by the author(s). The material, as presented, does not necessarily reflect any position of the Fisheries Society of Nigeria, its officers, or members. Papers presented at FISON meetings are subject to publication review by Editorial Committees of the Fisheries Society of Nigeria. Electronic reproduction, distribution, or storage of any part of this paper for commercial purposes without the written consent of the Fisheries Society of Nigeria is prohibited. Permission to reproduce in print is restricted to an abstract of not more than 300 words; illustrations may not be copied. The abstract must contain conspicuous acknowledgement of where and by whom the paper was presented. Write (FISON), P. O. Box 2607 . Wrapa, Lagos.
Librarian, Fisheries Society of Nigeria (FISON), P. O. Box 2607 Apapa,

\section{ABSTRACT}

Major sections (head, trunk and tail) of six fish species from the Warri River were measured in order to determine which was the largest and most fleshy. Besides Ethmalosa fimbriata (37.31\%) the trunk length was over $40 \%$ of the standard length in the fish species. Based on the length and breadth the trunk was larger than the tail and head in all species and could be the bulkiest and most fleshy region. The sequence of the trunk surface area was Brycinus macrolepidotus > B.nurse > Pellonula leonensis> Liza grandisquamis> Mugil cephalus> Ethmalosa fimbriata.

Keywords: Head, trunk, tail, surface area, flesh, fishes, Warri River.

\section{INTRODUCTION}

The families Characidae (Order Characiformes) Clupeidae (Clupeiformes) and Mugilidae (Perciformes) though diverse were selected for this study because they have certain features in common. They are elongated fishes with silvery-white sides and belly. They have cycloid scales and no spines; they are friendly to handle. They are shore and surface water dwellers. The characids and clupeids are compressed while the mugilids are cylindrical (Fischer et al.,1981; Idodo- Umeh,2003). The fish body consist of head, trunk and tail (Bond, 1979) but only the head length is frequently measured and used for fish description though it contains insignificant portion of flesh, contrasting to the bulky trunk and tail. There are few studies (Araoye,2004; Adedeji and Araoye, 2006; Olele and Obi, 2006) that have considered the trunk for their studies.

The fish muscle is very rich in high quality protein (Eyo 2001). Therefore evaluation of the part of the body which has the greatest spread of flesh is extremely important for choice of fish for human consumption and marketing. This study attempts to evaluate the head, trunk and tail sizes of six selected members of characidae, clupeidae and mugilidae which are of commercial significance from the Warri River.

\section{MATERIALS AND METHODS}

The Warri River is located within Latitude $5^{\circ} 21^{\prime}-6^{\circ} 00^{\prime} \mathrm{N}$ and Longitude $5^{\circ} 24^{\prime}-$ $6^{\circ} 21^{\prime} \mathrm{E}$. It flows from its source at UtagbaUno through Otorho-Abraka, Agbarho to Warri and continues to Forcados to join the Forcados River estuary which enters the Atlantic Ocean. The vegetation consists of fresh water and mangrove swamp forest. The multipurpose industralized river and tributaries have artisanal fishing grounds and the main market beach is a fresh-fish landing and commercial place in the environ.

Fish samples were obtained from fishermen at the Warri main market beach in Warri from February to September, 2007. They were immediately stored in a 
cooler containing ice blocks and transported to the laboratory. They were identified with standard guides (Fischer $e t$ al., 1981, Egborge,1994; Olaosebikan and Raji, 1998; Idodo-Umeh, 2003). Length of fish parts (head, trunk and tail) were measured in centimeters according to Bond (1979) and Olele and Obi (2006) expressed as percentage of standard length. Each fish was chopped into head, trunk and tail pieces with a sharp knife, weighed in grams and expressed as percentage of standard -length weight. Area of trunk was determined by multiplying trunk length by body depth.

\section{RESULTS AND DISCUSSION}

Two hundred and eighty eight (288) specimens of six species: Brycinus macrolepidotus Valenclennes, B. nurse Ruppel (characidae), Ethmalosa fimbriata(Bowdich), Pellonula leonensis Reagan(clupeidae) and Liza grandisquamis Valenciennes, Mugil cephalus Linnaeus(Mugilidae) were studied.

The morphometric data are shown in tables 1-7. The results revealed that the trunk was greater in length than the caudal part and the head in all the six fish species. Besides Ethmalosa fimbriata (37.31\%), the trunk was over $40 \%$ of the standard length in all the fish species. In terms of weight, the trunk in the six species was above $55 \%$ of the standard-length weight. Except E. fimbriata (caudal $30.84 \%$ ) and B.macrolepidotus $(24.57 \%$ somewhat equal to head $24.90 \%)$ the caudal $(30.06 \%)$ was longer than the head $(24.71 \%)$ in the fish species studied.

Therefore in all the six species, the trunk had the largest area for attachment and carriage of flesh muscles, judging by the rectangular shape (table7). This is explicable in terms of the nearly uniform body trunk depth which extended to the anal fin insertion, from where the tails tapers posteriorly like a cone to the base of its fin. It is the tapering that reduced the tail-flesh content of these fishes. Anteriorly the head of each of them is largely a bony cranium and gills apparatus with little flesh.

Though we recognise that preserved canned fish (sardines and pilchards) and Stockfish are headless, heads of fish are served in meals in eateries (restaurants), hostels and homes at celebrations, ceremonies and entertainment in Nigeria. In many cultures, much food-importance is attached to fish head. Hence fish- mongers and marketers gain more from sale of whole fish and fish head than headless fish. Gills may be discarded in wet fish but in dry fish they are eaten. Once the gills are removed, the heads of fish species in this study which are not extraordinarily ossified can be masticated.

This study revealed the sequence of surface area of the trunk of B.macrolepidotus $>B$. nurse $>P$. leonensis > $L$ grandisquamis $>\mathrm{M}$. cephalus > E.fimbriata and absolutely confirmed the trunk of these selected fish species as the largest flesh region of the body.

Table 1: Body proportions of Brycinus macrolepdotus from Warri River expressed as percentage of standard length.

\begin{tabular}{llllll}
\hline Parameters & $\mathrm{N}$ & Mean & SE & Min & Max \\
\hline HL & 81 & 24.90 & 0.24 & 21.04 & 30.57 \\
TrL & 81 & 50.54 & 0.33 & 42.04 & 54.67 \\
CL & 81 & 24.57 & 0.24 & 20.25 & 29.18 \\
BD & 81 & 26.19 & 0.38 & 18.75 & 37.19 \\
HWt & 81 & 21.09 & 0.54 & 3.16 & 30.99 \\
TrWt & 81 & 63.74 & 0.73 & 44.77 & 80.78 \\
CWt & 81 & 15.17 & 0.35 & 10.25 & 24.26 \\
\hline
\end{tabular}


Table 2: Body proportions of Brycinus nurse from Warri River expressed as percentage of standard length (SL)

\begin{tabular}{llllll}
\hline Parameters & $\mathrm{N}$ & Mean & SE & Min & Max \\
\hline HL & 37 & 23.34 & 0.14 & 21.66 & 25.24 \\
TrL & 37 & 47.96 & 0.26 & 46.31 & 52.10 \\
CL & 37 & 28.69 & 0.35 & 22.69 & 30.77 \\
BD & 37 & 25.12 & 0.30 & 22.40 & 29.56 \\
HWt & 37 & 9.16 & 0.25 & 15.06 & 21.55 \\
TrWt & 37 & 66.06 & 0.45 & 63.95 & 73.98 \\
CWt & 37 & 14.78 & 0.22 & 11.25 & 16.52 \\
\hline
\end{tabular}

Table 3: Body proportions of Ethmalosa fimbriata from Warri River expressed as percentage of length (SL).

\begin{tabular}{llllll}
\hline Parameters & $\mathrm{N}$ & Mean & SE & Min & Max \\
\hline HL & 36 & 31.84 & 0.36 & 23.89 & 34.38 \\
TrL & 36 & 37.31 & 0.43 & 32.71 & 45.63 \\
CL & 36 & 30.84 & 0.29 & 28.13 & 33.64 \\
BD & 36 & 33.19 & 0.28 & 30.70 & 38.89 \\
HWt & 36 & 30.26 & 0.93 & 14.29 & 38.73 \\
TrWt & 36 & 57.37 & 0.96 & 50.23 & 76.80 \\
CWt & 36 & 12.37 & 0.53 & 5.42 & 18.44 \\
\hline
\end{tabular}

Table 4: Body proportions of Pellonula leonensis from Warri River expressed as percentage of standard length.

\begin{tabular}{lllllllllll}
\hline Parameters & $\mathrm{N}$ & Mean & SE & Min & Max & & Mean & SE & Min & Max \\
\hline HL & 40 & 24.41 & 0.23 & 21.45 & 27.27 & HWt & 15.63 & 0.64 & 8.81 & 20.61 \\
TrL & 40 & 45.79 & 0.43 & 40.00 & 50.68 & TrWt & 67.10 & 0.71 & 57.85 & 75.93 \\
CL & 40 & 29.81 & 0.45 & 23.29 & 34.74 & CWt & 17.28 & 0.72 & 12.71 & 28.55 \\
BD & 40 & 20.35 & 0.60 & 13.16 & 28.03 & & & & & \\
\hline
\end{tabular}

Table 5: Body proportions of Liza grandisquamis from Warri River expressed as percentage of standard length.

\begin{tabular}{lllllllllll}
\hline Parameters & $\mathrm{n}$ & mean & SE & Min & Max & & Mean & SE & Min & Max \\
\hline HL & 35 & 25.24 & 0.19 & 22.73 & 27.48 & HWt & 17.54 & 0.33 & 14.32 & 21.35 \\
TrL & 35 & 43.41 & 0.32 & 38.17 & 47.55 & TrWt & 62.75 & 0.58 & 55.41 & 68.52 \\
CL & 35 & 31.34 & 0.32 & 27.97 & 35.82 & CWt & 19.71 & 0.35 & 15.48 & 26.11 \\
BD & 35 & 25.77 & 0.27 & 22.44 & 28.24 & & & & & \\
\hline
\end{tabular}

Table 6: Body proportions of Mugil cephalus from Warri River as percentage of standard length (SL).

\begin{tabular}{lllllllllll}
\hline Parameters & N & Mean & SE & Min & Max & & Mean & SE & Min & Max \\
\hline HL & 59 & 25.86 & 0.11 & 25.70 & 29.70 & HWt & 21.58 & 0.21 & 15.06 & 23.53 \\
TrL & 59 & 41.75 & 0.16 & 38.89 & 43.45 & TrWt & 56.71 & 0.30 & 47.34 & 61.13 \\
CL & 59 & 30.39 & 0.15 & 28.28 & 32.46 & CWt & 21.70 & 0.28 & 19.12 & 34.84 \\
BD & 59 & 25.85 & 0.30 & 19.81 & 29.47 & & & & & \\
\hline
\end{tabular}


Key:

$\begin{array}{llllllll}\text { HL } & \text { Head length } & \text { TrL } & \text { Trunk length } & \text { CL } & \text { Caudal length } & \text { BD } & \text { Body depth } \\ \text { HWt } & \text { Head weight } & \text { TrWt } & \text { Tail weight } & \text { CWt } & \text { Caudal weight } & & \end{array}$

Table 7: Length, depth and area of trunks of six fish species from the Warri River.

\begin{tabular}{lllllll}
\hline Fish taxa & \multicolumn{5}{c}{ Dimension of trunk (\% of standard length) } \\
\hline & $\mathrm{N}$ & Length & & Depth & Area \\
\cline { 2 - 7 } Bryanus macrolepidotus & 81 & 50.54 & $\mathrm{x}$ & 26.19 & $=$ & $1,323.64$ \\
Brycinus nurse & 37 & 47.96 & $\mathrm{x}$ & 25.12 & $=$ & $1,204.76$ \\
Ethmalosa fimbriata & 36 & 37.31 & $\mathrm{x}$ & 33.19 & $=$ & $1,238.32$ \\
Liza grandisquamis & 35 & 43.41 & $\mathrm{x}$ & 25.77 & $=$ & $1,118.68$ \\
Mugil cephalus & 59 & 41.75 & $\mathrm{x}$ & 25.85 & $=$ & $1,079.24$ \\
Pellonula leonensis & 40 & 45.79 & $\mathrm{x}$ & 20.35 & $=$ & 931.83 \\
\hline
\end{tabular}

\section{REFERENCES}

Adedeji, R. A. and Araoye, P. A. (2006). Study and characterization in the growth of body parts of Synodontis schall (pisces: Mochokidae) from Asa Dam, Ilorin, Nigeria. Nigerian Journal of Fisheries. 3(1): 219244.

Araoye. P. A. (2004). The head-body and Head-body length relationship of Synodontis schall (Bloch and Schneider 1801) in Asa lake Ilorin, Nigeria. In Proceedings of the $19^{\text {th }}$ Annual Conference Fisheries Society of Nigeria (FISON), Ilorin, Nigeria. $29^{\text {th }}$ November to $3^{\text {rd }}$ December, 2004. ed. P. A. Araoye. 288-291pp.

Bond, C. E. (1979). Biology of fishes. W. B. Saunders, London. 514pp.

Egborge, A. B. M. (1994). Water pollution in Nigeria Biodiversity and chemistry of Warri River. Ben Miller books; 331pp.

Eyo, A. A. (2001). Fish processing technology in the tropics. University of Ilorin press. 403pp.

Fischer, W., Bianchi, G. and Scott W. B. (1981). F. A. O. Identification sheet for fishery purposes. 34,47(in part). F. A. O. pag. Var.

Idodo-Umeh, G. (2003). Freshwater Fishes of Nigeria. Idodo-Umeh publishers, Benin City.232pp.

Olaosebikan, B. D. and Raji, A. (1998). Fish guide to Nigeria Freshwater Fishes. Federal College of freshwater fisheries technology, New Bussa. 106pp.

Olele, N. F. and Obi, A (2006). Morphometric Growth in Citharinus citharus in Onah Lake Delta State, Nigeria. Nigerian Journal of Fisheries 2(290-298) 